\title{
Structual evolution during calcination and sintering of a (La0.6Sr0.4)0.99CoO3- nanofiber prepared by electrospinning
}

Simonsen, Søren Bredmose; Shao, Jing; Zhang, Wenjing (Angela)

Published in:

Nanotechnology

Link to article, DOI:

10.1088/1361-6528/aa73a6

Publication date:

2017

Document Version

Peer reviewed version

Link back to DTU Orbit

Citation (APA):

Simonsen, S. B., Shao, J., \& Zhang, W. (2017). Structual evolution during calcination and sintering of a $\left(\mathrm{La}_{\mathrm{C}} \mathrm{Sr}\right)_{2} \mathrm{CoO}_{3}$ nanofiber prepared by electrospinning. Nanotechnology, 28(26), [265402]. https. $/$ dd $: 0$ rg/ $98.1088 / 1361-6528 / a a 73 a 6$

\section{General rights}

Copyright and moral rights for the publications made accessible in the public portal are retained by the authors and/or other copyright owners and it is a condition of accessing publications that users recognise and abide by the legal requirements associated with these rights.

- Users may download and print one copy of any publication from the public portal for the purpose of private study or research.

- You may not further distribute the material or use it for any profit-making activity or commercial gain

- You may freely distribute the URL identifying the publication in the public portal 
Structural evolution during calcination and sintering of a $\left(\mathrm{La}_{0.6} \mathrm{Sr}_{0.4}\right)_{0.99} \mathrm{CoO}_{3-\delta}$ nanofiber prepared by electrospinning

This content has been downloaded from IOPscience. Please scroll down to see the full text.

Download details:

IP Address: 130.225.94.40

This content was downloaded on 17/05/2017 at 12:29

Manuscript version: Accepted Manuscript

Simonsen et al

To cite this article before publication: Simonsen et al, 2017, Nanotechnology, at press:

https://doi.org/10.1088/1361-6528/aa73a6

This Accepted Manuscript is: (c) 2017 IOP Publishing Ltd

During the embargo period (the 12 month period from the publication of the Version of Record of this article), the Accepted Manuscript is fully protected by copyright and cannot be reused or reposted elsewhere.

As the Version of Record of this article is going to be / has been published on a subscription basis, this Accepted Manuscript is available for reuse under a CC BY-NC-ND 3.0 licence after the 12 month embargo period.

After the embargo period, everyone is permitted to copy and redistribute this article for non-commercial purposes only, provided that they adhere to all the terms of the licence https://creativecommons.org/licences/by-nc-nd/3.0

Although reasonable endeavours have been taken to obtain all necessary permissions from third parties to include their copyrighted content within this article, their full citation and copyright line may not be present in this Accepted Manuscript version. Before using any content from this article, please refer to the Version of Record on IOPscience once published for full citation and copyright details, as permission will likely be required. All third party content is fully copyright protected, unless specifically stated otherwise in the figure caption in the Version of Record.

When available, you can view the Version of Record for this article at:

http://iopscience.iop.org/article/10.1088/1361-6528/aa73a6 


\title{
Structural evolution during calcination and sintering of a
} $\left(\mathrm{La}_{0.6} \mathrm{Sr}_{0.4}\right)_{0.99} \mathrm{CoO}_{3-\delta}$ nanofiber prepared by electrospinning

\author{
S. B. Simonsen ${ }^{\mathrm{a}}$, J. Shao ${ }^{\mathrm{b}}$ and W. Zhang ${ }^{\mathrm{a} *}$ \\ ${ }^{a}$ Department of Energy Conversion and Storage, Technical University of Denmark.
}

Frederiksborgvej 399, Roskilde 4000, Denmark.

${ }^{b}$ College of Chemistry and Enviromental Engineering, Shenzhen University, Nanhai Road 3688, Shenzhen 518000, P.R. China.

*corresponding author:W.Zhang:wenz@dtu.dk

Design of 3-dimensional metal oxide nanofibers by electrospinning is being widely explored. However, the impacts of calcination and sintering on the resulting morphology remain unknown. For the first time, $\left(\mathrm{La}_{0.6} \mathrm{Sr}_{0.4}\right)_{0.99} \mathrm{CoO}_{3-8}(\mathrm{LSC})$ nanofiber, which is among the most promising electrode materials for solid oxide fuel cells, was synthesized by sol-gel electrospinning. By elevating the temperature in oxygen using in situ transmission electron microscopy, we discovered the structural transitions from nanofibers to nanotubes and then to nano-pearl strings. This facile and up-scalable method can be widely applied to design metal oxide one-dimensional nanomaterials with precise control in both geometry (nanofiber, nanotube and nano-pearl string) and surface area (by varying grain size).

\section{Introduction}

Nanofibers are one-dimensional (1D) nanomaterials that have unique physicochemical properties such as

2 high surface area, high strength, high electronic/ionic conductivity and 1-dimensionality. One of important applications is catalysis, where 1D materials of carbon [1] or metal oxides [2] have been 4 synthesized to replace conventional catalyst systems and increase the catalytic performance. The performance and commercialization of such 1D materials strongly depend on further development of 6 synthesis methods that allow for the control of both composition and structure while still being costeffective and up-scalable. 
1 Electrospinning is an efficient and cost-effective method to produce 1D materials [3-5]. Combined with 2 sol-gel chemistry and calcination, electrospinning has been used to produce a variety of 1D metal oxide 3 nanomaterials that bring remarkable performance enhancement in energy devices (e.g. lithium ion 4 batteries [6, 7], solid oxide fuel cells [8-10]). Moreover, by using co-axial spinnerets or by adjusting 5 calcination parameters, nanofibers can be transformed into nanotubes [11], nano-pearl-strings [12] or 6 nanobelts [13]. These 1D materials with hierarchical structure provide exceptionally high surface-to7 volume ratio, facile strain relaxation and improvement in electrochemical performance. In particular, the catalysts with 1D nanotube structures has attracted much attention, owning to the shorter diffusion 9 lengths, higher electronic conductivity and higher surface area [6, 14].

10 For example, nano-pearl-string $\mathrm{TiNb}_{2} \mathrm{O}_{7}$ nanofibers were fabricated by annealing electrospun nanofibers 11 (containing precursors and polymer binders) at $1000^{\circ} \mathrm{C}$ in air for $10 \mathrm{~h} \mathrm{[12].} \mathrm{As} \mathrm{anode} \mathrm{material} \mathrm{for} \mathrm{lithium}$ 12 batteries, this material shows efficient 1D electron transport along longitudinal direction, improved 13 connectivity with electronic and ionic sources and short diffusion distance. $\mathrm{TiO}_{2}$ hollow nanofibers were 14 synthesized by electrospinning using a dual nozzle, where a solution containing PVP and titanium 15 isopropoxide was filled in the outer layer of the nozzle with its inner core filled by mineral oil. After 16 calcination, the resulting nanofibers with the hollow geometry showed twice higher rate capability 17 compared to that of pristine $\mathrm{TiO}_{2}$ nanofiber at $5{ }^{\circ} \mathrm{C}$ due to shorter diffusion distance of lithium ion and 18 higher lithium ion flux [11]. However, electrospinning with dual nozzle is complicated and difficult to be 19 scaled up for industrial production. Therefore, a simple, precise and up-scalable process is required to design hierarchical structures of nanofibers and enhance their performance in energy devices.

21 A conventional method of producing metal oxide ceramic nanofibers involves three steps: 1) mixing 22 precursors, carrier polymer and solvent; 2) electrospinning the mixture into polymeric nanofiber 23 membrane; 3 ) converting the polymeric nanofibers to metal oxide nanofibers by calcination and sintering. 24 The major purpose of the third step is often considered to be the decomposition of precursors and removal 25 of polymers. Convention electron microscopy is often used to offer valuable insight into the 1D structure 26 before and after calcination and sintering, but such post mortem of analysis does not allow one to follow 27 the structural evolution of the nanofibers. The structural evolution of electrospun metal oxide 1D 28 materials during calcination and sintering is therefore generally unknown.

29 In situ transmission electron microscopy (in situ TEM) is a method that allows for direct imaging of nano30 materials during chemical reactions with nanoscale resolution and has been used to describe 31 nanostructural dynamics [15-21]. In the present work, we use in situ TEM to reveal the structural 32 evolution of an electrospun $\left(\mathrm{La}_{0.6} \mathrm{Sr}_{0.4}\right)_{0.99} \mathrm{CoO}_{3-\delta}$ (LSC) nanofiber while it was calcined and sintered in 33 oxygen. Complementary to the structural analysis, thermogravimetric analysis (TGA) is used to obtain 
1 insight in the chemical reactions as a function of temperature. LSC is chosen in this study because this

2 perovskite has been intensively studied for electrochemical devices, e.g. solid oxide fuel cells [22].

\section{2. Experimental}

$4 \quad 2.1$ Electrospinning

$5 \mathrm{La}\left(\mathrm{NO}_{3}\right) \cdot 6 \mathrm{H}_{2} \mathrm{O}, \mathrm{Sr}\left(\mathrm{NO}_{3}\right)_{2}$ and $\mathrm{Co}\left(\mathrm{NO}_{3}\right)_{3} \cdot 6 \mathrm{H}_{2} \mathrm{O}$ were dissolved in deionized $\mathrm{H}_{2} \mathrm{O}$ at a molar ratio of

6 0.6:0.4:1 in order to synthesis $\left(\mathrm{La}_{0.6} \mathrm{Sr}_{0.4}\right)_{0.99} \mathrm{CoO}_{3-\delta}$ (LSC). The solution was stirred at $60^{\circ} \mathrm{C}$ until complete 7 dissolution. Polyvinylpyrrolidone (PVP) with an average molecular weight of 1,300,000 was used as 8 carrier polymer in this experiment. A desired amount of PVP powder was added to the above solution. In 9 this case, the mass ratio of PVP powder to nitrate salts was set as 0.4 . Higher ratios of PVP over nitrate 10 salt resulted in finer LSC nanofibers. Lower ratios of PVP resulted in electrosprayed droplets instead of 11 nanofibers. The solution was stirred at $60^{\circ} \mathrm{C}$ until a clear pink solution was formed. The mixture was then 12 loaded into a $10 \mathrm{ml}$ syringe with a 21 gauge stainless steel needle attached to the tip of the syringe. The 13 syringe was then mounted on a syringe pump. During electrospinning, the mixture was pumped out of the 14 needle at an injection rate of $0.3 \mathrm{ml} / \mathrm{h}$ with an electrical field of $4.4 \mathrm{kV} / \mathrm{cm}$. A grounded aluminum (Al) 15 foil was used as the collector to collect the electrospun nanofibers.

\subsection{In situ TEM}

17 The in situ TEM experiments were performed using a Titan 80-300 (FEI) electron microscope equipped 18 with a differentially pumped environmental cell [23] operated at $300 \mathrm{keV}$. Heating was facilitated by an 19 Aduro 300 heating holder (Protochips Inc.) which is a chip based heating holder. The as-spun nanofiber 20 membrane was peeled off from the Al collector foil and deposited on a thermal chip (Protochips Inc.) by 21 adding a droplet of the electrospun nanofibers suspended in acetone to the surface of the chip and 22 allowing the acetone to evaporate in air at room temperature. The chips used for the experiments were so23 called "no-carbon" type, which means that the sample is supported directly by the ceramic heating 24 membrane of the chip. The in situ experiment was performed by exposing the sample to 2 mbar $\mathrm{O}_{2}$ (AGA 25 6.0) while constantly ramping the temperature by $5^{\circ} \mathrm{C} / \mathrm{min}$ and recording time-lapsed TEM images and 26 diffraction patterns of the same fiber. Image analysis is performed using the software ImageJ. The fiber 27 diameters were measured by drawing a straight line from edge to edge across the fiber. The diameters of 28 nanograins were measured by outlining the grains using the Polygon selection tool and calculating a 29 diameter from the measured area by assuming a circular geometry. Line intensity profiles across the fiber 30 were acquired by using the Plot profile tool. The line profiles were averaged along the length of the fiber. 31 Crystal lattice distances measured in selected area electron diffraction (SAED) pattern were compared 32 with crystallographic data from the ICSD database. 


\subsubsection{Temperature calibration}

2 Since the commercial thermal chips were calibrated by the company only in vacuum, it is necessary to

3 calibrate the temperatures for the in situ experiment in the relevant gas at the relevant pressure. The

4 calibration is here based on a comparison of two oxidation experiments of carbon black super 65 (Timcal)

5 in 2 mbar $\mathrm{O}_{2}$ with a constant temperature ramping rate of $10^{\circ} \mathrm{C} / \mathrm{min}$, by using the TEM holder from

6 Protochips and a TEM heating holder from DENSsolutions. The later heating holder/provides the

7 temperature feedback based on a 4-point-probe resistive measurement of the micro hotplate, which is

8 assumed to be reliable under the present conditions. The relative motion and shrinkage of the carbon

9 black were measured in the two experiments. Based on the comparison of the two results, we found that 10 the set temperature of the Protochips holder was consistent with the measured temperature from the 11 DENSsolutions holder within $10^{\circ} \mathrm{C}$.

\section{$12 \quad$ 2.2.2 Electron beam effects}

13 From the TEM images, the LSC particle sizes were measured by using a circular approximation to their 14 projected area. All measurements were performed manually by using the software ImageJ. Before performing the actual experiments, it is mandatory to understand and control artefacts that may be induced by the electron beam so that they can be eliminated. The electron beam effects were examined by exposing a nanofiber to a beam current density of $830 \mathrm{e} / \mathrm{nm}^{2} \mathrm{~s}$ in $2 \mathrm{mbar} \mathrm{O}_{2}$ at room temperature in 1 hour. Under these conditions, the exposed nanofiber reduced its diameter at a rate of ca. $0.5 \mathrm{~nm} / \mathrm{min}$. To minimize the beam induced nanofiber shrinkage in the in situ TEM calcination experiment, the low electron beam current density of ca. $800 \mathrm{e} / \mathrm{nm}^{2} \mathrm{~s}$ was used through the entire experiment. The TEM images were acquired every forth minute and the electron beam was removed from the region in the time

22 between image acquisitions. Including time needed for focusing and imaging, the sample regions used in 23 the present analyses were exposed to the electron beam for ca. $40 \mathrm{~s}$ per image, giving a total exposure 24 time of ca. 32 min. Based on the measured shrinkage rates, the total shrinkage of the fibers caused by the 25 electron beam can therefore be estimated to $16 \mathrm{~nm}$, which is negligible compared to calcination induced 26 shrinkage (a reduction of several hundreds of nanometers in diameter). It should however be noted that 27 the projected beam induced shrinkage may accelerate as the fiber becomes thinner and that the beam 28 induced shrinkage therefore could be underestimated. However, after the in situ TEM calcination 29 experiment, the regions monitored during the experiment were compared with regions that were 30 previously unexposed to the electron beam. Similar nanofiber structures were found in both types of 31 regions. It is therefore concluded that the influence of the electron beam was not dominating the structural 32 dynamics presented in this study.

\section{$33 \quad 2.3$ Thermogravimetric analysis}


1 Thermogravimetric analysis (TGA) was performed by Netzsch STA 409CD Thermobalance on the 2 electrospun LSC nanofibers, electrospun PVP nanofibers as well as three precursors: $\left(\mathrm{La}\left(\mathrm{NO}_{3}\right) \cdot 6 \mathrm{H}_{2} \mathrm{O}\right.$, $3 \mathrm{Sr}\left(\mathrm{NO}_{3}\right)_{2} \mathrm{Co}\left(\mathrm{NO}_{3}\right)_{3} \cdot 6 \mathrm{H}_{2} \mathrm{O}$. The samples were spread out on the surface of an $\mathrm{Al}_{2} \mathrm{O}_{3}$ sample holder mounted 4 vertically in the test chamber. The TGA experiments were performed in a flow of $50 \mathrm{Nml} / \mathrm{min} 0.2 \%$ $5 \quad \mathrm{O}_{2} / \mathrm{N}_{2}$ so the oxygen partial pressure used here is identical to that of the in situ TEM experiment. The 6 temperature was ramped from room temperature to $1000^{\circ} \mathrm{C}$ at $5^{\circ} \mathrm{C} / \mathrm{min}$ as in the in situ TEM experiment.

\section{3. Results and discussion}

\section{$8 \quad 3.1$ TGA results}

9 The results of the thermogravimetric analysis (TGA) of the electrospun $\left(\mathrm{La}_{0.6} \mathrm{Sr}_{0.4}\right)_{0.99} \mathrm{CoO}_{3-\delta}$ (LSC) 10 nanofibers are presented in Figure 1. Figure 1a reveals a complex mass-temperature dependence of the 11 electrospun nanofibers (red, labelled as LSC Nanofiber) with several temperature intervals of accelerated 12 mass losses. The accelerated mass losses are observed as peaks in the derivative of the mass loss curve 13 (Figure 1b). This complexity could be expected, since the calcination process includes the dehydration of 14 crystal water, the decomposition of three different precursors and in addition the decomposition of PVP. 15 To help in identifying the temperature intervals for the decomposition of each precursor and PVP, Figure 16 1a also presents results from pure PVP nanofibers (blue), $\mathrm{La}\left(\mathrm{NO}_{3}\right) \cdot 6 \mathrm{H}_{2} \mathrm{O}$ powder (orange), $\mathrm{Sr}\left(\mathrm{NO}_{3}\right)_{2}$ 17 powder (green) and $\mathrm{Co}\left(\mathrm{NO}_{3}\right)_{3} \cdot 6 \mathrm{H}_{2} \mathrm{O}$ powder (purple). $\mathrm{Co}\left(\mathrm{NO}_{3}\right)_{3} \cdot 6 \mathrm{H}_{2} \mathrm{O}$ and $\mathrm{La}\left(\mathrm{NO}_{3}\right) \cdot 6 \mathrm{H}_{2} \mathrm{O}$ are the first 18 precursors to dehydrate and decompose (ca. $30-230^{\circ} \mathrm{C}$ and $30-600^{\circ} \mathrm{C}$, respectively), while $\operatorname{Sr}\left(\mathrm{NO}_{3}\right)_{2}$ 19 decomposes at higher temperatures (ca. 500-700 $\mathrm{C}$ ). The decomposition of PVP initiates at ca. $350{ }^{\circ} \mathrm{C}$ 20 with an exothermic peak centered at $410^{\circ} \mathrm{C}$ (Figure 1b). The mass loss peaks for the LSC nanofiber can 21 be correlated with the mass losses for the individual precursors and for the pure PVP. It is therefore 22 reasonable to assume that the precursors and PVP decompose at the same temperature intervals when 23 mixed in the electrospun nanofibers. 


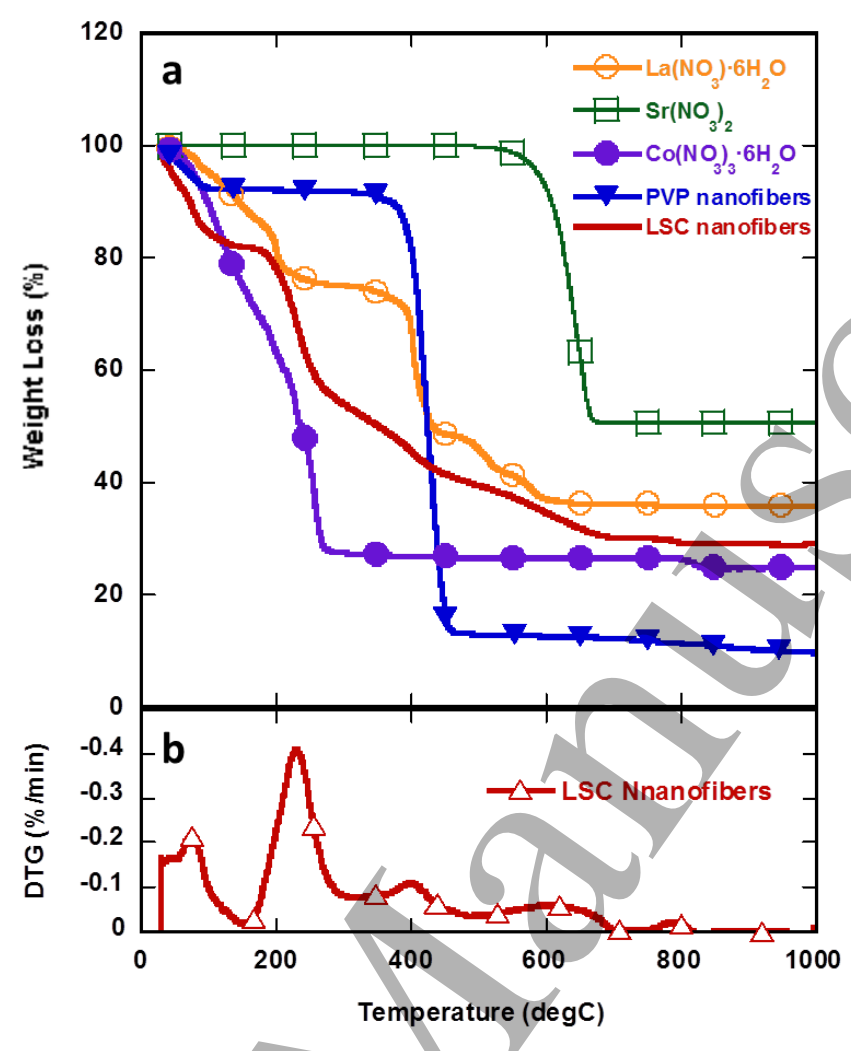

Figure 1: a) The mass loss as a function of temperature of $\left(\mathrm{La}\left(\mathrm{NO}_{3}\right) \cdot 6 \mathrm{H}_{2} \mathrm{O}, \mathrm{Sr}\left(\mathrm{NO}_{3}\right)_{2}, \mathrm{Co}\left(\mathrm{NO}_{3}\right)_{3} \cdot 6 \mathrm{H}_{2} \mathrm{O}, \mathrm{PVP}\right.$ nanofibers and LSC nanofibers; b) The derivative mass loss of LSC nanofibers as a function of temperature. During thermogravimetric analysis, all samples were exposed to $0.2 \% \mathrm{O}_{2} / \mathrm{N}_{2}$ at a constant ramping rate of $5{ }^{\circ} \mathrm{C} / \mathrm{min}$.

\subsection{In situ TEM imaging}

In situ TEM images of the same nanofiber at selected temperatures are presented in Figure 2a-h (A movie

of the entire in situ TEM image sequence is available in the Supplementary information). From Figure 2 ,

8 it can be observed that the fiber diameter is reduced as a function of temperature. In addition, the internal

9 structure of the fiber is changed from an amorphous structure to the appearance of nanograins in the fiber.

10 To quantify these observations, the diameters of the fiber and of the individual nanograins were 11 measured. Figure 3 a presents the diameter of the nanofiber (blue) and the mean diameter of nano-grains 12 in the nanofiber (red) as a function of temperature. When initiating the calcination process, the nanofiber 13 has a diameter of ca. $800 \mathrm{~nm}$ (Figure 3a). While ramping the temperature from room temperature (RT) to $14330^{\circ} \mathrm{C}$, the diameter decreases to ca. $700 \mathrm{~nm}$ (Figure 3a). According to Figure 1, this is mainly due to 15 loss of crystal water and decomposition of $\mathrm{Co}\left(\mathrm{NO}_{3}\right)_{3}$. At $350{ }^{\circ} \mathrm{C}$, which is the onset temperature for PVP 16 decomposition (Figure 1a), the outer surface of the nanofiber appears corroded (Figure 2c). As the 17 temperature is increased further, the nanofiber diameter is rapidly reduced to ca. $350 \mathrm{~nm}$ at $410{ }^{\circ} \mathrm{C}$ 
1 (Figure 3a), which is mainly due to PVP decomposition according to Figure 1. At higher temperature, the 2 nanofiber diameter is approximately constant (Figure 3a), despite of the mass losses due to the 3 decomposition of $\mathrm{La}\left(\mathrm{NO}_{3}\right)$ and $\mathrm{Sr}\left(\mathrm{NO}_{3}\right)_{2}$ (Figure 1) and the change in nanofiber structure (Figure 2e-h). A 4 small increase in the fiber diameter is, however, observed at ca. $600{ }^{\circ} \mathrm{C}$ (Figure 3a), where the $\operatorname{Sr}\left(\mathrm{NO}_{3}\right)_{2}$ is 5 decomposed with the highest rate (Figure 1).

6 One type of structural change in the high temperature range is the formation, coarsening and sintering of 7 nano-grains in the nanofiber (Figure 2e-h, Figure 3a). At $510{ }^{\circ} \mathrm{C}$, a mean grain size of ca. $15 \mathrm{~nm}$ is 8 observed. When temperature is increased further, the mean grain size of the nanofiber increases (Figure 9 3a). Smaller grains are expected below $510^{\circ} \mathrm{C}$, but they are too small to be well-defined in the TEM 10 images which represent projections of the nanofiber. Therefore, the exact onset temperature of grain 11 formation cannot be determined from this experiment. To verify the validity of the grain size analysis by 12 in situ TEM, we also carried out grain sizes analysis on nanofibers that were calcined in air in a tube 13 furnace at constant temperatures of $600^{\circ} \mathrm{C}, 800^{\circ} \mathrm{C}$ and $1000^{\circ} \mathrm{C}$ for 4 hours (Figure 3a, black X's). It can 14 be seen that the in situ and post mortem grain sizes are consistent.

15

16 

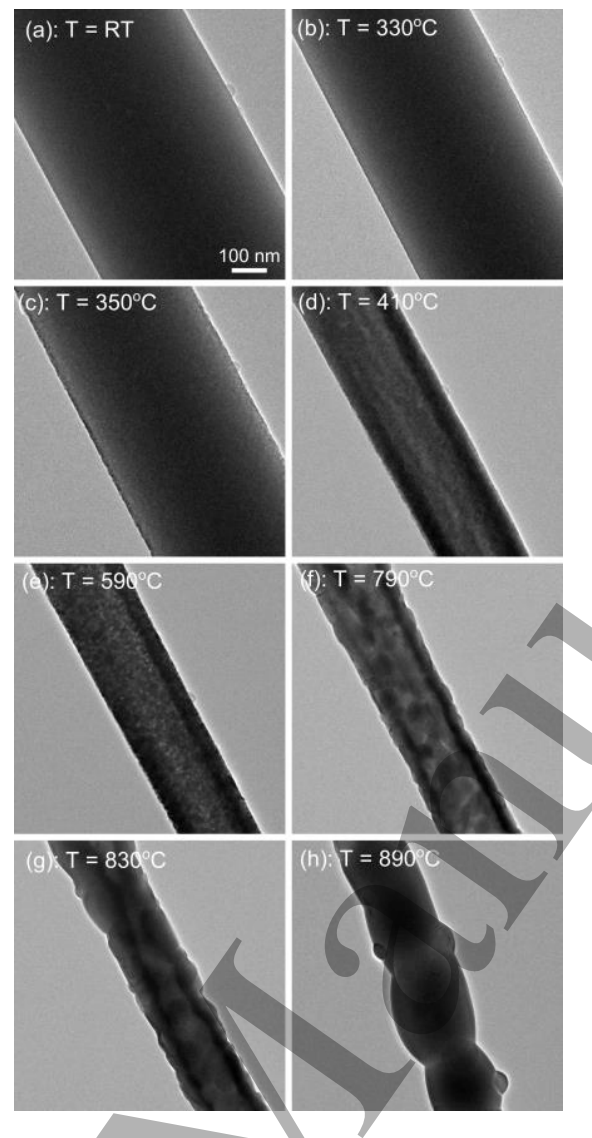

2 Figure 2: Time-lapsed TEM images recorded in situ on the same nanofiber during exposure to $2 \mathrm{mbar}_{2} \mathrm{O}_{2}$ and at the constant 3 temperature ramping rate of $5^{\circ} \mathrm{C} / \mathrm{min}$ from room temperature (RT) to $890^{\circ} \mathrm{C}$. The images present the fiber at (a) $\mathrm{RT}$, (b) $\mathrm{T}=$ $4330^{\circ} \mathrm{C}$, (c) $\mathrm{T}=350^{\circ} \mathrm{C}$, (d) $\mathrm{T}=410^{\circ} \mathrm{C}$, (e) $\mathrm{T}=590^{\circ} \mathrm{C}$, (f) $\mathrm{T}=790^{\circ} \mathrm{C}$, (g) $\mathrm{T}=830^{\circ} \mathrm{C}$ and (h) $\mathrm{T}=890^{\circ} \mathrm{C}$. The nanofiber contains $5 \mathrm{La}\left(\mathrm{NO}_{3}\right) \cdot 6 \mathrm{H}_{2} \mathrm{O}, \mathrm{Sr}\left(\mathrm{NO}_{3}\right)_{2}, \mathrm{Co}\left(\mathrm{NO}_{3}\right)_{3} \cdot 6 \mathrm{H}_{2} \mathrm{O}$ and $\mathrm{PVP}$.

6 A closer inspection of Figure 2d-f reveals another type of nanofiber structure: there is a strong contrast

7 between the dark edge and the light center of the nanofiber. According to mass-thickness contrast theory, 8 this means that the sample density is lower in the nanofiber center relatively to that near the edges, 9 indicating the nanofiber has a nanotube structure with a low density core. Averaged intensity line profiles 10 across the nanofiber at different temperatures are presented in Figure 3b. For a dense fiber, the intensity 11 profiles will show gradually lower intensity when moving from the edge to the center (See for example 12 the lines for the RT and $250^{\circ} \mathrm{C}$ in Figure $3 \mathrm{~b}$ ). For temperatures ranging from $370{ }^{\circ} \mathrm{C}$ to $790{ }^{\circ} \mathrm{C}$, it is on 13 the contrary observed that the intensity near the center increases relative to the edges (Figure $3 b$ ). This 14 shows that the density of the fibers is lower at the center than near the surface. The observation of an 15 apparent low density core can either be explained a) by the presence of different types of materials, 16 meaning high density materials at the positions near the edges and low density materials at the core, or b) 17 by a void at the core of the fiber - a so-called nanotube. At higher temperatures the low density core 18 disappears, which is clearly observed at $890{ }^{\circ} \mathrm{C}$ (Figure 3b). The disappearance of the low density core at 
1 the higher temperatures can be explained by the coarsening of nanograins within the fiber. At $830{ }^{\circ} \mathrm{C}$, for 2 example, the mean grain size is ca. $1 / 3$ of the nanofiber diameter (Figure $2 \mathrm{~g}$ and Figure $3 \mathrm{~b}$ ). At $8900^{\circ} \mathrm{C}$, 3 instead of the low density core structure, a so-called nano-pearl string structure with individual particles 4 sizes of ca. $200 \mathrm{~nm}$ is observed (Figure 2h). Further increase in temperature resulted in rapture of the 5 nano-pearl string structure into individual nanoparticles.

(a)

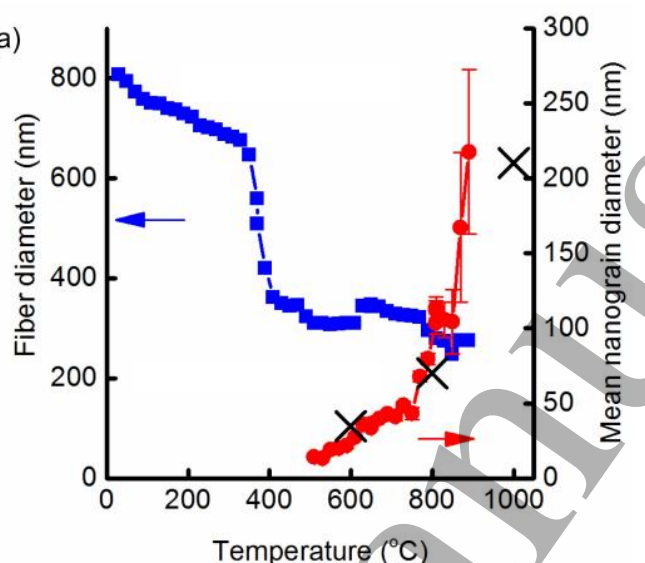

(b)

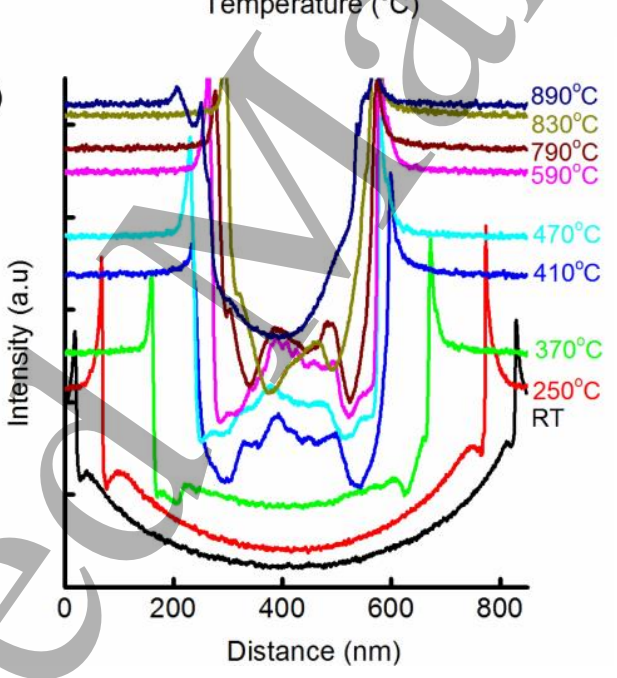

Figure 3: (a) Fiber diameter (line marked by squares) and the mean LSC nanograin diameter (line marked by spheres) as a 8 function of temperature for the fiber in Figure 2. Error bars for the mean LSC nanograin size refer to the standard deviation. 9 Black $X$ is the mean grain sizes of the nanofibers that were calcined in a tube furnace. (b) Intensity line profiles across the fiber in 10 Figure 2 for the indicated temperatures. The line profiles are averaged along the length of the fiber.

\section{$11 \quad 3.3$ in situ TEM diffraction}

12 Selected area electron diffraction (SAED) was performed on the same LSC nanofiber during the in situ 13 experiment. At $480^{\circ} \mathrm{C}$, the broad diffuse signal was observed, which means that the nanofiber has an 14 amorphous structure and that the LSC phase was not yet formed (Figure 4a). Combined with the TEM 15 image information, this indicates that the onset temperature of oxide nano-grain formation is in the 
1 temperature interval of $480-510{ }^{\circ} \mathrm{C}$. This is close to the onset temperature of $\operatorname{Sr}\left(\mathrm{NO}_{3}\right)_{2}$ decomposition 2 (Figure 1). A ring pattern confirming the presence of nanocrystals is observed at $620^{\circ} \mathrm{C}$ (Figure 4b). At 3 higher temperature, the number of diffraction spots decreases so that the ring pattern breaks up (Figure 4 4b-d). This is consistent with the coarsening of the nanograins with temperature increase. Moreover, the 5 diffraction patterns observed at temperatures from 620 to $890{ }^{\circ} \mathrm{C}$ (Figure $4 \mathrm{~b}-\mathrm{d}$ ) were found to be 6 consistent with cubic perovskite-type $\mathrm{La}_{0.6} \mathrm{Sr}_{0.4} \mathrm{CoO}_{3-\delta}$ It should be noted that a rhombohedral structure 7 would be expected for LSC at room temperature, and the cubic structure is expected at these elevated temperatures [24].
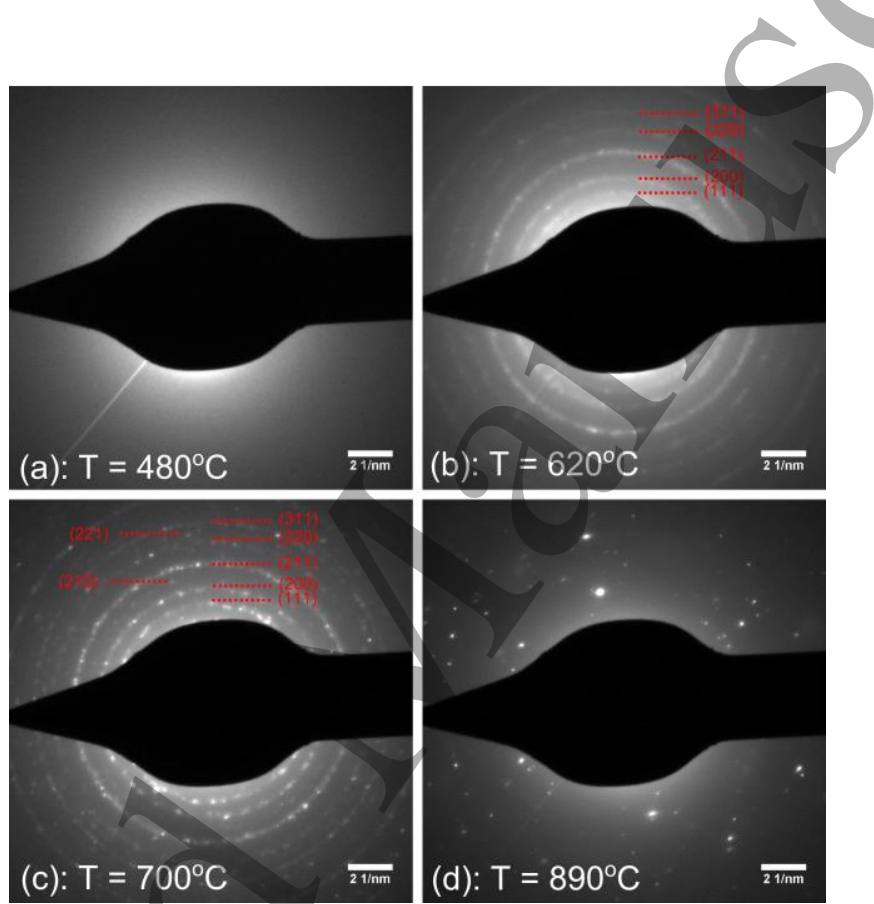

Figure 4: (a-f) Time-lapsed SAED patterns recorded in situ on the same LSC-PVP fiber as presented in Figure 2 during the exposure to $2 \mathrm{mbar}_{2}$ and at the constant temperature ramping rate of $5{ }^{\circ} \mathrm{C} / \mathrm{min}$. Miller indices for cubic $\mathrm{La}_{0.6} \mathrm{Sr}_{0.4} \mathrm{CoO}_{3 \cdot \mathrm{r}}$ at 900 $\mathrm{K}[24]$ is added to (b) and (c) for comparison (red). 
Among those materials, cubic perovskite-type $\mathrm{La}_{0.6} \mathrm{Sr}_{0.4} \mathrm{CoO}_{3-\delta}$ is considered as one of the best-performing catalysts due to the enhanced electrocatalytic activity toward oxygen reduction and increased ionic conductivity at intermediate temperature [25-28]. In this experiment, the calcination temperature to obtain cubic structure of $\mathrm{La}_{0.6} \mathrm{Sr}_{0.4} \mathrm{CoO}_{3-\delta}$ was found to be ca. $620^{\circ} \mathrm{C}$. This temperature is significantly lower than the typical calcination temperatures for conventional methods [29-31], which range from 800 to $1200^{\circ} \mathrm{C}$. Therefore, the 1D materials made by our sol-gel assisted electrospinning with lower energy consumption open ways to many applications of metal oxide that required versatile and affordable synthesis methods.

\subsection{Fiber structure evolution}

9 Based on the in situ TEM experiments, we can conclude that perovskite LSC nanotubes can be obtained 10 at relatively low temperatures $\left(620^{\circ} \mathrm{C}\right.$ to $\left.800{ }^{\circ} \mathrm{C}\right)$. Furthermore, the nanotubes can be obtained alone by controlling the calcination and sintering process rather than using more complex methods such as dualnozzle electrospinning which is considered to be difficult to scale up for industrial applications. Sintering at slightly higher temperatures $\left(800-850^{\circ} \mathrm{C}\right)$ transformed the nanotube structure into a dense nanofiber. At the high sintering temperature of ca. $890^{\circ} \mathrm{C}$, the nano-pearl string was formed without the rapture of the 1D structure. Nano-pearl strings has previously been used as anode materials for rechargeable lithium batteries to provide high electron transport along the longitudinal direction [12].

It is also important to mention that both temperature and ramping rate are important factors determining the structure of nanofibers during calcination and sintering. Calcination of the same nanofiber at $800{ }^{\circ} \mathrm{C}$ for $3 \mathrm{~h}$ at higher ramping rate of $15^{\circ} \mathrm{C} / \mathrm{min}$ did not result in the formation of nanofibers, but a mixture of short nanotubes and broken pieces as shown in Figure S2a in the supplementary information. This indicates that the fibers were broken apart into small pieces during temperature ramping at high rate. This fracture of the fibers into small disconnected pieces suggests that the fibers were torn apart by a rapid process, almost like an explosion.

32 the residue of the core is pushed to the surface, driven by the relatively high internal pressure and thereby 33 making a transition from nanofiber to low density core fiber during the shrinkage in diameter due to the 
1 loss of oxidized PVP. Further increase in temperature allows coarsening and sintering of grains on the 2 nanofiber with a slight decrease in nanofiber diameter (as shown in Figure 3b). At the temperature of 800

$3{ }^{\circ} \mathrm{C}$, the low density core structure disappears as a result of continuing growth in grain size to form a dense 4 nanofiber.

5 The driving forces for the structural evolution are double-folded: 1) the decomposition of polymer that is 6 present in the initial nanofiber, and 2) sintering behaviors of nanograins on the nanofiber. A controlled 7 calcination process can likely be applied in producing other metal oxides in the form of nanofibers, 8 nanotubes and nano-pearl strings. Yet the structural transition temperatures might vary depending on the 9 properties of precursors and carrier polymers.

10 Preliminary electrochemical tests of the symmetrical cell, composed of a Gadolinium-doped Ceria (CGO) 11 electrolyte and electrodes made of the LSC nanofibers, showed a lower polarization resistance for all 12 temperatures in the temperature range of $500-800^{\circ} \mathrm{C}$, as compared to the symmetric cell composed of 13 CGO electrolyte and LSC nanoparticle electrodes (see details in the supplementary information). An 14 additional electrochemical study is in progress to, investigate the possible advantages of using LSC fibers 15 as electrodes in fuel and electrolysis cells.

\section{4. Conclusions}

17 The structure evolution of a $\left(\mathrm{La}_{0.6} \mathrm{Sr}_{0.4}\right)_{0.99} \mathrm{CoO}_{3-\delta}$ (LSC) nanofiber was determined as a function of 18 temperature in oxygen by in situ TEM. Three distinct 1D geometries were obtained simply as a result of 19 temperature ramping: nanotube $\left(620-800^{\circ} \mathrm{C}\right)$, dense nanofiber $\left(800-850{ }^{\circ} \mathrm{C}\right)$ and nano pearl-string $(890$ $20{ }^{\circ} \mathrm{C}$ ). Prior to the in situ TEM calcination and sintering, the fiber was prepared by electrospinning of LSC 21 precursors and PVP and had no internal structures. Above a temperature of $620{ }^{\circ} \mathrm{C}$, the LSC nanotube 22 was composed of cubic perovskite-type nanograins that coarsened and sintered as a function of 23 temperature. The observations show that different metal oxide nanofiber geometries can be obtained by 24 simply controlling the calcination and sintering process of electrospun nanofibers. This represents a 25 facile, inexpensive and up-scalable route to design structured 1D metal oxide nanomaterial.

\section{Acknowledgements}

27 The authors thank H.C Ørsted Postdoc Fellowship for providing funding to the project. Carsten Gynther 28 Sørensen, DTU Energy Conversion is acknowledged for performing the TGA experiments. The A.P. 29 Møller and Christine Mc-Kinney Møller Foundation are gratefully acknowledged for their contribution 30 toward the establishment of the Center for Electron Nanoscopy in the Technical University of Denmark. 


\section{References}

2 [1] De Jong K P and Geus J W 2000 Carbon nanofibers: Catalytic synthesis and applications Catal. Rev. Eng. 42 481-510

[2] Noon D, Seubsai A and Senkan S 2013 Oxidative Coupling of Methane by Nanofiber Catalysts ChemCatChem 5 146-9

[3] Zhang W and Pintauro P N 2011 High-performance nanofiber fuel cell electrodes. ChemSusChem 4 1753-7

[4] Choi J, Wycisk R, Zhang W, Pintauro P N, Lee K M and Mather P T 2010 High conductivity perfluorosulfonic acid nanofiber composite fuel-cell membranes. ChemSusChem 3 1245-8

[5] Zhang W, Brodt M W and Pintauro P N 2011 Nanofiber cathodes for low and high humidity hydrogen fuel cell ECS Transactions 41 891-889

[6] Han H, Song T, Bae J-Y, Nazar L F, Kim H and Paik U 2011 Nitridated $\mathrm{TiO}_{2}$ hollow nanofibers as an anode material for high power lithium ion batteries Energy \& Environ. Sci. 44532

[7] Kumar P S, Sundaramurthy J, Sundarrajan S, Babu V J, Singh G, Allakhverdiev S I and Ramakrishna S 2014 Hierarchical nanofibres for energy harvesting, production and environmental remediation Energy \& Environ. Sci. 7 3192-222

[8] Zhi M, Lee S, Miller N, Menzler N H and Wu N 2012 An intermediate-temperature solid oxide fuel cell with electrospun nanofiber cathode Energy \& Environ. Sci. 57066

[9] Zhao E, Jia Z, Zhao L, Xiong Y, Sun C and Brito M E 2012 One dimensional $\mathrm{La}_{0.8} \mathrm{Sr}_{0.2} \mathrm{Co}_{0.2} \mathrm{Fe}_{0.8} \mathrm{O}_{3-\delta} / \mathrm{Ce}_{0.8} \mathrm{Gd}_{0.2} \mathrm{O}_{1.9}$ nanocomposite cathodes for intermediate temperature solid oxide fuel cells J. Power Sources 219 133-9

[10] Chou C-C, Huang C-F and Yeh T-H 2013 Characterization and catalytic activity of $\mathrm{La}_{0.6} \mathrm{Sr}_{0.4} \mathrm{Co}_{0.2} \mathrm{Fe}_{0.8} \mathrm{O}_{3-\delta}-\mathrm{yttria}$ stabilized zirconia electrospun nano-fiber as a cathode catalyst Ceram. Int. 39 S549--S553

[11] Yuan T, Zhao B, Cai R, Zhou Y and Shao Z 2011 Electrospinning based fabrication and performance improvement of film electrodes for lithium-ion batteries composed of $\mathrm{TiO}_{2}$ hollow fibers J. Mater. Chem. 2115041

[12] Tang K, Mu X, van Aken P a., Yu Y and Maier J 2013 "Nano-Pearl-String" $\mathrm{TiNb}_{2} \mathrm{O}_{7}$ as anodes for rechargeable lithium batteries Adv. Energy Mater. 3 49-53

[13] Wang $\mathrm{H}, \mathrm{Ma} D$, Huang $\mathrm{Y}$ and Zhang $\mathrm{X} 2012$ Electrospun $\mathrm{V}_{2} \mathrm{O}_{5}$ nanostructures with controllable morphology as high-performance cathode materials for lithium-ion batteries. Chemistry 18 898793

[14] Kivi I, Anderson E, Möller P, Nurk G and Lust E 2012 Influence of microstructural parameters of LSC cathodes on the oxygen reduction reaction parameters J. Electrochem. Soc. 159 F743-50

[15] Baker R T K, Harris P S and Thomas R B 1974 Direct observation of particle mobility on a surface in a gaseous environment Surf. Sci. 46 311-6 
[16] Crozier P A and Datye A K 2000 Direct observation of reduction of PdO to Pd metal by in situ electron microscopy Stud. Surf. Sci. Catal. 130 D 3119-24

[17] Hansen P L, Wagner J B, Helveg S, Rostrup-Nielsen J R, Clausen B S and Topsøe H 2002 Atomresolved imaging of dynamic shape changes in supported copper nanocrystals Science $2952053-$ 5

[18] Wang C M, Kwak J H, Kim D H, Szanyi J, Sharma R, Thevuthasan S and Peden C H F 2006 Morphological Evolution of $\mathrm{Ba}\left(\mathrm{NO}_{3}\right)_{2}$ Supported on $\alpha-\mathrm{Al}_{2} \mathrm{O}_{3}(0001)$ : An In Situ TEM Study J. Phys. Chem. B $11011878-83$

[19] Simonsen S B, Dahl S, Helveg S and Johnson E 2009 Direct observations of $\mathrm{CeO}_{2}$-catalyzed soot oxidation at the nano-scale using environmental transmission electron microscopy S AE Int. J. Mater. Manuf. 1 199-203

[20] Fujita T, Guan P, McKenna K, Lang X, Hirata A, Zhang L, Tokunaga T, Arai S, Yamamoto Y, Tanaka $\mathrm{N}$, Ishikawa Y, Asao N, Yamamoto Y, Erlebacher J and Chen M 2012 Atomic origins of the high catalytic activity of nanoporous gold Nat. Mater. $11775-80$

[21] Simonsen S B, Agersted K, Hansen K V, Jacobsen T, Wagner J B, Hansen T W and Kuhn L T 2015 Environmental TEM study of the dynamic nanoscaled morphology of NiO/YSZ during reduction Appl. Catal. A Gen. 489 147-54

[22] Adler S B 2004 Factors governing oxygen reduction in solid oxide fuel cell cathodes Chem. Rev. 104 4791-844

[23] Hansen T W and Wagner J B 2014 Catalysts under controlled atmospheres in the transmission electron microscope ACS Catal. 4 1673-85

[24] Sonntag R, Neov S, Kozhukharov V, Neov D and ten Elshof J . 1997 Crystal and magnetic structure of substituted lanthanum cobalitites Phys. B Condens. Matter 241-243 393-6

[25] Takeda Y, Kanno R, Noda M, Tomida Y and Yamamoto O 1987 Cathodic polarization phenomena of perovskite oxide electrodes with stabilized zirconia J. Electrochem. Soc. 134 2656-61

[26] Kishimoto H, Sakai N, Horita T, Yamaji K, Brito M E and Yokokawa H 2007 Cation transport behavior in SOFC cathode materials of $\mathrm{La}_{0.8} \mathrm{Sr}_{0.2} \mathrm{CoO}_{3}$ and $\mathrm{La}_{0.8} \mathrm{Sr}_{0.2} \mathrm{FeO}_{3}$ with perovskite structure Solid State lonics 178 1317-25

[27] Hjalmarsson $P$, Søgaard $M$ and Mogensen M 2008 Electrochemical performance and degradation of $\left(\mathrm{La}_{0.6} \mathrm{Sr}_{0.4}\right)_{0.99} \mathrm{CoO}_{3-8}$ as porous SOFC-cathode Solid State lonics 179 1422-6

[28] Darbandi A J, Enz T and Hahn H 2009 Synthesis and characterization of nanoparticulate films for intermediate temperature solid oxide fuel cells Solid State Ionics 180 424-30

[29] Januschewsky J, Ahrens M, Opitz A, Kubel F and Fleig J 2009 Optimized $\mathrm{La}_{0.6} \mathrm{Sr}_{0.4} \mathrm{CoO}_{3-\delta}$ thin-film electrodes with extremely fast oxygen-reduction kinetics Adv. Funct. Mater. 19 3151-6

[30] Zhao F, Zhang L, Jiang Z, Xia C and Chen F 2009 A high performance intermediate-temperature solid oxide fuel cell using impregnated $\mathrm{La}_{0.6} \mathrm{Sr}_{0.4} \mathrm{CoO}_{3-\delta}$ cathode J. Alloys Compd. 487 781-5

[31] Lust E, Küngas R, Kivi I, Kurig H, Möller P, Anderson E, Lust K, Tamm K, Samussenko A and Nurk G 
1

2

3

4

5

6

7

8

9

10

11

12

13

14

15

16

17

18

19

20

21

22

23

24

25

26

27

28

29

30

31

32

33

34

35

36

37

38

39

40

41

42

43

44

45

46

47

48

49

50

51

52

53

54

55

56

57

58

59

60
1

2

2010 Electrochemical and gas phase parameters of cathodes for intermediate temperature solid oxide fuel cells Electrochim. Acta 55 7669-78

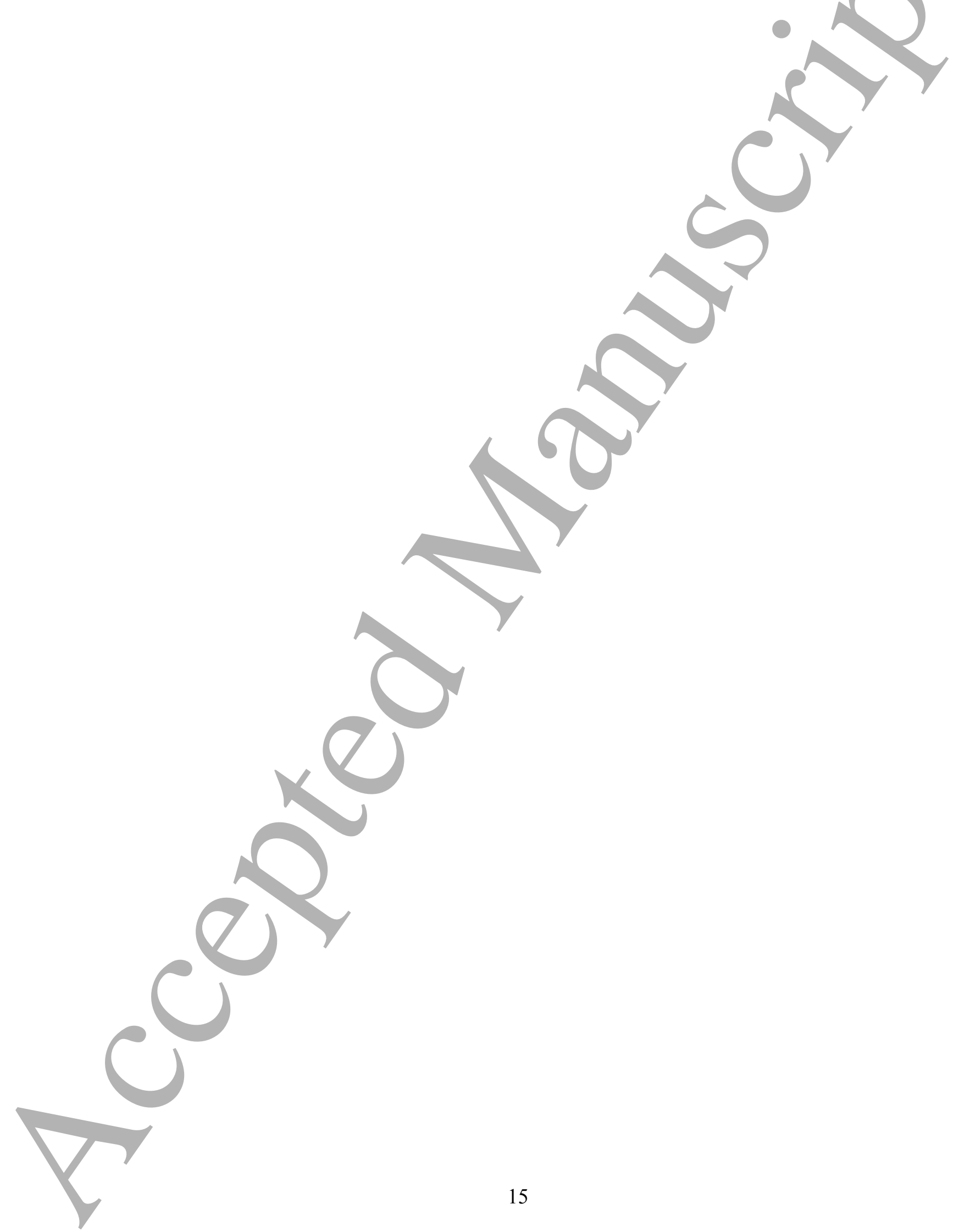

